New Zealand journal of industrial relations, 1983, 8, 23-29

\title{
Formal collective agreements in New Zealand private sector industrial relations
}

\author{
A.J. Geare*
}

This article provides a classification and analysis of the different types of formal collective arrangements reached in the private sector, discussion as to why management and unions should select a particular type, and data on the arrangements actually reached.

\section{Introduction}

Theoretical definitions of industrial relations have varied in their approach to the rules that govern the work environment. Some consider rules as the central concern (Dunlop, 1958; Flanders, 1970), while others consider the process of obtaining the rules as being of the greater importance (Laffer, 1968; Somers, 1969). The definition favoured by this writer focusses on the objectives of the principal actors, but sees the rules as the means by which they obtain their objectives (Geare, 1977). All approaches however clearly acknowledge the significance of the rules to industrial relations.

Rules can be formal, given standing by statute or informal house agreements, or unwritten custom and practice. They may result from negotiation or arbitration. They may be substantive rules, which determine the basic conditions of work, or be procedural rules, which are concerned with how the substantive rules may be "interpreted, enforced and from time to time altered" (Flanders, 1970, p.99) or, as usually occurs, both types.

Since, by their nature, informal rules cannot be classified or documented accurately, this paper will examine formal collective arrangements in the private sector. The paper will submit a classification, data, and discussion on the collective arrangements created in 1980 , and the advantages of each type.

\section{Classification by the statutes}

The major statute concerning collective arrangements is the Industrial Relations Act 1973 (IR Act). In addition there are three particular "industry" acts: the Aircrew Industrial Tribunal Act 1971 (AIT Act), the Waterfront Industry Act 1976 (WI Act), and the Agricultural Workers Act 1977 (AW Act).

Figure 1 shows the classification given by the statutes. Unfortunately, it is inadequate and illogical. Indeed a former Secretary of Labour called it "Illiterate nonsense" (Woods, 1977, p.24). The major problem is that an "award" under the IR Act and the AIT Act, can be reached both by conciliation or arbitration. Under the $A W A c t$ awards can be reached by conciliation or arbitration or voluntary settlement. This inconsistency and illogicality

* Senior Lecturer in Industrial Relations, University of Otago, Dunedin. The author wishes to thank the journal's referees for their comments on an earlier draft. 
Figure 1 Classification of collective arrangements by statute

\begin{tabular}{lccc}
\hline IR Act & AIT Act & WI Act & AW Act \\
\hline Award & Award & Order & Award \\
Collective Agreement & & & \\
Composite Agreement & & & \\
Voluntary Agreement & & & \\
\hline
\end{tabular}

has baffled even the authorities, leading to the Agricultural Workers (Tobacco Growers) Award - reached by voluntary settlement - being printed, incorrectly as a collective agreement.

\section{Alternative classifications}

Recently both Szakats (1981) and Howells (1980) have proposed similar classifications which overcome some of the illogicalities of the statutes. They suggest there are five classes of collective arrangements:

Class 1

Class 2

Class 3

Class 4

Class 5

\author{
Voluntary collective agreements \\ Voluntary composite collective agreements \\ Conciliated collective agreements \\ Awards \\ Quasi-collective agreements
}

Both authors discuss the process by which the above arrangements are reached and their nature. Taken in isolation, their classification has merit. Unfortunately the classification cannot be isolated from reality and must work in with the statutes. The statutes, of course, determine the titles actually given to printed collective arrangements. Their classification and the actual titles create the probability of total confusion.

For anyone studying New Zealand industrial relations, the classification has many pitfalls. Reference in the literature, in case studies or legal cases will frequently be made to awards and occasionally to voluntary agreements and collective agreements (voluntary). The probability is high that the student would consider awards to go in Class 4 and voluntary agreements probably in Class 1 while being unsure as to which class the collective agreement (voluntary) belonged. However in 95 percent of instances awards should be in Class 3 and voluntary agreements should always go in Class 5 .

Admittedly each document contains a memorandum which explains how it was created. This is of some value if the document is available but of no value whatsoever in the majority of situations when reference only is made to the document.

The above classification, along with that made by the statutes, also fails to differentiate between principal and supplementary documents. A principal document is one which stands by itself with regard to questions governing the work environment. In many cases, principal documents will copy much that is in a "parent" award - but the document will be considered the principal indicator of the rules. A supplementary document is one which is the authority for only a small proportion of rules and must be read in conjunction with a principal document. Failure to recognise that there are these two major types of documents can lead to false conclusions. For example Table 1 shows that, for 1979-1981, collective agreements (voluntary) form a much higher proportion of total collective arrangements than they did in 1975-1977. If all documents were taken to be principals, then this suggests that there is a trend away from conciliation and hence a growing independence of union officials and management negotiators. An alternative possibility is that the growth in of conciliation. Table 2 below byows supplementary documents rather than a rejection tive agreements were supplementary. 
Table 1 Work of the Arbitration Court

\begin{tabular}{lcccc}
\hline $\begin{array}{l}\text { Year } \\
\text { ending } \\
31 \text { March }\end{array}$ & $\begin{array}{c}\text { Awards: } \\
\text { (some } \\
\text { arbitration) }\end{array}$ & $\begin{array}{c}\text { Awards: } \\
\text { (registered } \\
\text { conciliated } \\
\text { agreements) }\end{array}$ & $\begin{array}{c}\text { Collective } \\
\text { agreements: } \\
\text { (registered } \\
\text { voluntary } \\
\text { settlements) }\end{array}$ & $\begin{array}{c}\text { Composite } \\
\text { agreements: }\end{array}$ \\
\hline 1975 & 35 & 192 & 181 & 5 \\
1976 & 20 & 265 & 383 & (not given \\
1977 & 9 & 245 & 246 & separately \\
1978 & 8 & 280 & 434 & since 1975) \\
1979 & 8 & 303 & 416 & \\
1980 & 23 & 251 & 482 & 530 \\
1981 & 9 & 385 & 2672 & \\
$1975-1981$ & 112 & 1921 & & \\
\hline
\end{tabular}

Source: Department of Labour Annual Reports, Wellington, 1975-1981.

\section{Proposed classification}

The proposed classification for arrangements made under the IR Act is illustrated in Table 2. The table also gives the numbers created in 1980 for each category. The classification differentiates between arrangements made by unregistered societies and those by registered unions, between those made independently of the procedures in the Act, those using conciliation, and those using arbitration. The arrangements are also categorized into principal and supplementary documents.

Table 2 Collective arrangements under the Industrial Relations Act 1973 reached in 1980

\begin{tabular}{lr}
\hline Collective arrangement & Number \\
\hline Involving registered unions & 7 \\
1) Awards: arbitrated (principal) & 263 \\
2) Awards: conciliated (principal) & 315 \\
3) Collective agreements (principal) & 196 \\
4) Collective agreements (supplementary) & 27 \\
5) Composite agreements (principal) & 10 \\
6) Composite agreements (supplementary) & 31 \\
Involving unregistered societies & 2 \\
7) Voluntary agreements (principal) & Voluntary agreements (supplementary) \\
\hline
\end{tabular}

\section{Choice of collective arrangements}

The type of collective arrangement settled, depends on the objectives of the parties and the standing of the worker group, For example, collective agreements and awards may only be negotiated by registered unions.

\section{Voluntary agreements}

An unregistered society may formalize their collective arrangements by filing them under the IR Act. Once filed the voluntary agreement has the same standing as a collective agreement. 
Except for the occasional deregistered union, societies have presumably decided that the advantages of registration (see Geare 1979, pp. 52-55, 74-81) are not significant. However, they are a minority - unions outnumber societies by 15 to 1 . The first advantage is that registration gives sole bargaining rights and protection from takeovers by break-away groups or other unions. This is significant if the society does not have virtually total support from the members. Secondly, a registered union is entitled to an unqualified preference clause which results in self-imposed compulsory unionism - with provisions for conscientious objectors. Voluntary agreements, according to section $141 \mathrm{~A}(2)$, are not able to have an unqualified preference clause although some do, in contravention to the law. The final advantage is that registration permits the use of conciliation and arbitration and this in turn allows, under sections 83 and 89 , - the "blanket clauses" - for any award (arbitrated or conciliated) to extend to all employers in the industry and in the relevant district (s).

The two latter advantages are obviously of greater significance to groups of workers dealing with large numbers of employers. As Table 3 suggests, most societies deal with

\section{Table 3 Societies which have not registered under the Industrial Relations Act 1973}

(a) Parties to voluntary agreements made in 1980

1. NZ Institute of Marine and Power Engineers Inc.

2. Northern Federation of Woodpulp, Paper and Paper Products Workers Inc.

3. Northern Totalisator and Allied Employees Association Inc.

4. United Mineworkers of NZ.

5. Southland Oystermans Society.

6. Gisborne Gas Workers Unions.

7. Wellington Regional Water Board Officers Association.

8. Northern Canterbury Electric Power Board Classified Officers Society Inc.

9. Central Canterbury Electric Power Board Classified Officers Society Inc.

10. Southern Canterbury Electric Power Board Classified Officers Society Inc.

11. Northcote Borough Council Senior Officers Association.

12. Joint Council for Local Authorities Services Salaried Employees Society.

13. Wellington District Boilermakers, Metal Workers Assistants, Iron and Steel Ship and Bridge Builders and Structural Steel Workers (Deregistered union).

(N.B. The boilermakers did not negotiate their agreement. The negotiations were undertaken by the Wellington Trades Council on their behalf).

(b) Parties to voluntary agreements current but not made in 1980

14. Ohai railway Transport Workers Guild.

15. Gisborne Share Fishermens Association Inc.

16. NZ Share Fishermens Association Inc.

17. Wellington Municipal Officers Association Inc.

18. Lyttelton Borough Council Intermediate Officers Association.

(c) Registered under, and party to award under, AW Act

19. NZ Farmworkers Association Inc.

one employer, or only a very few. Their potential members are concentrated and easier to recruit and the blanket provisions irrelevant. An exception is the NZ Farm Workers Association with scattered membership and numerous employers. This association is, however basically anti-union and was created simply to avoid the alternative of having farm workers under the coverage of the NZ Workers Union.

\section{Awards}

Registered unions and employers may opt to negotiate independently of the procedures in the IR Act, or to utilize the conciliation and arbitration services. 
Use of the procedures results in awards. Table 2 shows that 97.4 percent are conciliated with only 2.4 percent being arbitrated. (Table 1 shows that for 1975-1981 awards: 95.5 percent of the total were conciliated.) Thus although potentially available, arbitration is certainly not used as an easy way out. Indeed the Arbitration Court will refuse to arbitrate if the parties have not made adequate efforts to settle (s. 84(4)).

The principal reason why parties choose to use registration procedures is to take advantage of the blanket clauses discussed earlier. Whenever large numbers of employers are involved, the blanket clauses are of tremendous benefit to the union.

In a few cases, parties choose to use conciliation simply to benefit from the conciliator's knowledge and expertise. Some local authorities reverted from voluntary settlement to conciliation for this reason.

\section{Collective agreements}

Collective agreements are negotiated between a union and a single employer and hence the "blanket clauses" have no significance. In some cases, a principal document is negotiated because there is only one employer in that "industry" and district (as with local authorities). Often, however, an employer who is party to a collective agreement, either principal or supplementary, has differences as compared to other employers in terms of profitability, amenability, or mode of operation. The union thus sees advantages in negotiating with the employer separately. Conciliation is still available, but the advantages of negotiating voluntarily - greater freedom and fewer timing constraints - are seen to outweigh the benefits of conciliation.

Collective agreements (supplementary) involve an employer, already covered by an award. Apart from taking advantage of the differences mentioned above, a union will negotiate these supplementary agreements in order to increase the likelihood that the rules will be later accepted into the award - because of the numbers of employers already covered.

The majority of supplementary collective agreements negotiated in 1980 involved two unions only. The NZ Engine Drivers' Union was negotiating improved service and shift allowances, meal money and extra moneys for particular working conditions. The Canterbury Clerical Workers' Union was negotiating provisions whereby union subscriptions would be automatically deducted from the workers' wages every week or fortnight by the employer and remitted to the union each month. Under the Wages Protection Act 1964 such deductions are only legal if the employer has the written consent of the worker (s. 7(1))or unless the award or agreement rules otherwise (s.11). Hence the collective agreements negotiated absolve the union and the employer from having to get written permission from each worker for the automatic deductions.

\section{Composite agreements}

The purpose of the composite agreement is to substitute one agreement for many, on a major project or in a major concern. The concept was introduced in 1962 but did not prove popular as the procedure then specified was complex. The current procedure merely requires the employer(s) and unions to negotiate a voluntary settlement similar to that required for a collective agreement. The NZ Institute of Marine and Power Engineers is allowed to negotiate a composite agreement, under section 66(4), which deems it to be an industrial union for this purpose. In 1980, it negotiated one composite agreement. Table 2 shows that 10 of the 37 composite agreements were adjudged to be supplementary, the remaining 27 were adjudged principal documents.

Table 1 above indicated that five composite agreements were reported by the Department of Labour as being negotiated in the $1974-75$ year with no further mention in following years. This incorrectly implies that no more were negotiated. The Appendices to the 
Book of Awards for the seven calendar years $1974-1980$ show, respectively that 2, 28, 15 , $25,38,35$ and 37 composite agreements were negotiated.

\section{Biannual negotiations}

The IR Act specifies that every award or collective agreement remains in force for at least one year (s.92(1)) unless the Court agrees otherwise. There are a number of "double entries" in Table 2 with awards or agreements being negotiated twice in the year. This "double entry" applied to 13 awards (conciliated), 10 collective agreements (principal), two collective agreements (supplementary) and one composite agreement (principal). In addition, one arbitrated award was renegotiated later in the year, voluntarily, and was listed the second time as a collective agreement (principal).

\section{Other collective arrangements in force}

Table 2 above listed those collective arrangements created in 1980. There are others still in force in 1980 which were created in earlier years. Indeed, since the Act states that awards and agreements remain in force until superseded, or cancelled by the Court (s.92(5)), notwithstanding the fact that the maximum currency is three years, some go back a considerable time. In fact there were 41 industrial agreements still in force in 1980. An industrial agreement was defined by the Industrial Conciliation and Arbitration Act 1954, and could be reached either by conciliation or voluntary settlement and 41 of these were still in force in 1980.

\section{Collective arrangements under industry Acts}

Details of awards settled under the AW Act and the AIT Act are given in the Book of Awards, and the numbers are detailed in Table 4.

Table 4 Collective arrangements under industry acts

\begin{tabular}{lcc}
\hline & AW Act & AIT Act \\
\hline Award (arbitrated) & - & 1 \\
Award (conciliated) & 3 & 4 \\
Award (voluntary settlement) & 1 & not applicable \\
\hline
\end{tabular}

The AW Act does not define a collective agreement but does permit voluntary settlement of a dispute with the resulting agreement to be called an award (s.34). This necessitates a further classification, namely Award (voluntary settlement). To be a party to an award under the $A W A c t$, the workers' organisation must be registered under the act. This requires that they are either an incorporated society (NZ Farm Workers Association Inc.) or be a registered union under the IR Act (NZ Labourers Union etc and NZ Workers Union).

The AIT Act and the WI Act do not allow for voluntary settlement of disputes - they can only be settled by conciliation or arbitration. Under the WI Act, workers must be members of the waterside union of their location. All waterside unions are registered under the IR Act. Under the AIT Act, the workers' organisations may be registered under the IR Act (as, for example, the NZ Airline Pilots Association Union) but also includes the NZ Institute of Marine and Power Engineers Inc. which is unregistered. 


\section{Conclusion}

While it is by no means the primary problem facing New Zealand's industrial relations, the illogicalities and inconsistencies in New Zealand statutes in the naming and method of reaching collective arrangements does merit some action. It is hoped that this classification not only provides a more accurate description of collective arrangements reached in New Zealand's private sector but makes the situation more comprehensible.

\section{References}

Dunlop, J.T. (1958) Industrial relations systems New York, Holt.

Flanders, A. (1970) Management and unions London, Faber \& Faber.

Geare, A.J. (1977) The field of study of industrial relations Journal of industrial relations 19(4):274-285.

Geare, A.J. (1979) New Zealand industrial relations: legislation and practice Dunedin, Campbell \& James.

Howells, J.M. (1980) New Zealand. In R. Blanpain (Ed) International encyclopaedia for labour law and industrial relations The Netherlands, Kluwer.

Laffer, K. (1968) Industrial relations, its teaching and scope; an Australian experience Bulletin of the Institute for Labour Studies 5:9-26.

Somers, G. (1969) Bargaining power and industrial relations theory. In G. Somers (Ed) Essays in industrial relations theory Ames, Iowa State University.

Szakats, A. (1981) Introduction to the law of employment Wellington, Butterworths.

Woods, N. (1977) The industrial relations amending legislation of 1976 Wellington, Victoria University of Wellington (Occasional paper no. 21). 